Please do not remove this page

RMIT

UNIVERSITY

\title{
Alternative work schedule interventions in the Australian construction industry: A comparative case study analysis
}

Lingard, Helen; Townsend, Keith; Bradley, Lisa; Brown, Kerry

https://researchrepository.rmit.edu.au/esploro/outputs/9921860832401341/filesAndLinks?institution=61RMIT_INST\&index=null

Lingard, H., Townsend, K., Bradley, L., \& Brown, K. (2008). Alternative work schedule interventions in the Australian construction industry: A comparative case study analysis. Construction Management and Economics, 26(10), 1101-1112. https://doi.org/10.1080/01446190802389402

Document Version: Accepted Manuscript

Published Version: https://doi.org/10.1080/01446190802389402

Repository homepage: https://researchrepository.rmit.edu.au

(C) 2008 Taylor \& Francis

Downloaded On 2023/04/26 21:27:40 +1000

Please do not remove this page 
Thank you for downloading this document from the RMIT Research Repository.

The RMIT Research Repository is an open access database showcasing the research outputs of RMIT University researchers.

RMIT Research Repository: http://researchbank.rmit.edu.au/

\author{
Citation: \\ Lingard, H, Townsend, K, Bradley, L and Brown, K 2008, 'Alternative work schedule \\ interventions in the Australian construction industry: A comparative case study \\ analysis', Construction Management and Economics, vol. 26, no. 10, pp. 1101-1112.
}

See this record in the RMIT Research Repository at:

https://researchbank.rmit.edu.au/view/rmit:6516

Version: Accepted Manuscript

Copyright Statement:

(C) 2008 Taylor \& Francis

Link to Published Version:

http://dx.doi.org/10.1080/01446190802389402 


\title{
Alternative work schedule interventions in the Australian construction industry: a comparative case study analysis
}

\author{
Lingard, H, Townsend, K, Bradley, L and Brown, K
}

\begin{abstract}
Project-based construction workers in the Australian construction industry work long and irregular hours and experience higher levels of work-to-family conflict and burnout than office-based workers, giving rise to an interest in alternative work schedules as a means of supporting work-life balance. Alternative work schedules were implemented in four case study construction projects in Australia. Interventions differed between projects, with two implementing a compressed work week, and the others introducing reduced hours schedules (one of which was optional). Data were collected from each case study project, using various combinations of focus groups, surveys, interviews and daily diary collection methods. The results were mixed. The compressed work week appears to have been favourably received where it was introduced. However, waged workers still expressed concerns about the impact on their weekly 'take-home' pay. Attempts to reduce work hours by changing from a six to a five day schedule (without extending the length of the working day between Monday and Friday) were less favourably received. Waged workers, in particular, did not favour reduced hours schedules. The results confirm the existence of two distinct labour markets operating in the Australian construction industry and markedly different responses to alternative work schedules, based upon whether workers are waged or salaried. The results clearly show that attempts to improve work-life balance must take the structural characteristics of the industry's labour markets into consideration in the design of interventions. The impact of alternative work schedules is likely to be moderated by institutional working time regimes within the construction industry.
\end{abstract}

\section{Key words}

Work hours, alternative work schedules, work-life balance, labour market characteristics.

\section{Introduction}

\section{Non-standard, long and unsociable work hours}

In recent decades, the working hours of Australians have steadily increased, with most of the growth in per capita working hours coming from persons already in full time work (Campbell, 2002). Australia's working time regime places few institutional limits on working time and, in contrast to countries of the European Union, Australia has no placed statutory limits on the hours that can be worked (van Wanrooy \& Wilson, 2006). In many instances, Australian workers have limited control over the hours that they are working (Peetz, Townsend, Russell, Houghton, Fox \& Allan 2003).

The Relationships Forum Australia (RFA) has defined 'long working hours' (i.e. those at which family relationships are negatively affected) as working 45 or more hours per week (Shepanski \& Diamond, 2007). This includes both paid and unpaid overtime. Long working hours are linked to poor health, strained family relationships and ineffective parenting (Shepanski \& Diamond, 2007), role conflict, lower job satisfaction, increased stress, decreased productivity (Veiga, Baldridge \& Eddleston, 2004), employee turnover, absenteeism and burnout (Stavrou, 2005). Work hours have been consistently linked to difficulties in balancing work and personal life (Moen \& Yu, 2000; Tausig \& Fenwick 2001; Batt \& Valcour, 2003). Kodz, Davis, Lain, Sheppard et al. (2003) report that, in the United Kingdom, workers' satisfaction with life decreased with the number of hours worked. Following a multi-national study of workers in the United States, the United Kingdom and Hong Kong, Wharton \& Blair-Loy (2006) report that long hours (especially when combined with tight deadlines) increase workers' concerns that their work negatively impacts upon family life. 
Research has highlighted a mismatch between people's actual and preferred work hours (Reynolds, 2005). Reynolds \& Aletraris (2007) report that, for Australian men, the likelihood of wanting more hours reduces by $7 \%$ and the likelihood of wanting fewer hours increases by $5.6 \%$ for every additional hour worked. Also, when work hours are perceived to interfere with family life, Australian workers (both male and female) express stronger preferences for reduced work hours (Reynolds \& Aletraris, 2007). Similarly, Van Wanrooy \& Wilson (2006) report that significant numbers of Australian workers who work long hours (45 hours per week or more) believe their hours are too long and would prefer to work less.

\section{The construction industry}

The construction industry is a demanding work environment in which participants are expected to work long hours. Since 1985, the proportion of people in the Australian construction industry working more than 44 hours increased by $11 \%$ - one of the largest increases in any industry (Van Wanrooy \& Wilson, 2006). In the Australian construction industry, the average number of hours worked each week is 63 among site-based employees in direct construction activity, 56 hours among employees who worked mostly in site office and 49 among employees in the head office of construction companies (Lingard \& Francis 2004). Long working hours reinforce the gendered 'breadwinner-homemaker' model of family life, which assumes that workers do not have significant caring responsibilities and can therefore devote unlimited amounts of time to their paid work (HREOC, 2007). Not only is this model no longer relevant to modern society, this model also undermines attempts to encourage the entry of women (who are very substantially under-represented in the Australian construction industry) into construction careers. While Gershuny et al (2005) use three national household panel surveys to show that relative shares of domestic work are becoming more equal, Australian women continue to do a greater share of household labour than men, which restricts the time women can spend in paid work.

Construction industry workers are also expected to work non-standard work schedules, including regular weekend work. Non-standard or atypical work hours, requiring evening, night or weekend work, have been found to be particularly damaging to work-life balance, health and well-being (Ulker, 2006). Canadian research has linked weekend work with burnout, job stress and psychosomatic health problems (Jamal, 2004) and Australian researchers report weekend work and irregular shifts to be associated with higher work-family conflict among Australian men (Hosking \& Western, 2008). Irregularity of work hours has been identified as the most important variable affecting low marital quality among shift workers (White \& Keith, 1990), and non-standard work schedules have been found to affect separation or divorce rate among married people with children (Presser, 2000). Non-standard or atypical work hours, requiring evening, night or weekend work, are particularly damaging to work-life balance and family life. For example, parents working non-standard work schedules experience significantly lower levels of family functioning, more depressive symptoms and less effective parenting and their children are likely to experience social and emotional difficulties (Strazdins, Clements, Korda, Broom \& D'Souza, 2006). Regular weekend work has consistently been identified as a major source of dissatisfaction for projectbased Australian construction professionals (Lingard \& Francis, 2002).

\section{Alternative work schedules}

The recognition that non-standard, long, and unsocial hours have a negative impact has led to increased interest in alternative work schedules and flexible work practices designed to assist workers to achieve a more satisfactory work-life balance (Casper \& Buffardi 2004; Kelly \& Kalev 2006; Shockley \& Allen, 2007). Such practices include the modification of daily start and stop times (flexitime), compressed work weeks, part-time work and job-sharing. 
Empirical evidence suggests alternative work schedules can yield benefits, for example, flexitime (the modification of daily start and stop work times) is reported to improve employee productivity, job satisfaction and satisfaction with work schedule, as well as reducing absenteeism (Baltes, Briggs, Huff, Wright \& Neumann, 1999). Baltes et al (1999) also found that compression of the work week (reducing the number of days worked per week and lengthening the number of hours worked each day) has a similarly positive influence on productivity, job satisfaction, absenteeism and overall satisfaction. Although not all evidence supports the beneficial effect of alternative work schedules and there is a growing understanding that the impact of alternative work schedules depends upon whether these create 'good' or 'bad' jobs. Good jobs are characterised by training and development opportunities, high levels of social integration and equality of pay with workers on standard work schedules. Bad jobs are characterised by a lack of these things.

(Broschak, Davis-Blake \& Block, 2008).

\section{Aims}

Little is known about the effect of alternative work schedules in the construction industry context. The research described in this paper sought to address this gap by investigating workers' experiences following the implementation of various forms of alternative work schedule at four case study construction projects in Australia. This paper presents the results of this research and explores the impact of the alternative work schedules on the work-life balance of project-based workers in the construction industry. Industry and labour market variables influencing the impact of alternative work schedules are also discussed.

\section{Research methods}

\section{Sampling}

Case study projects were identified by member organizations of the Construction Industry Institute (Australia). To be included as a case, projects were required to be of a sufficient duration to enable data collection and the implementation of a work-life intervention. The agreement of the project management team to participate in the research was also a requirement. Data were collected from four case study projects during the course of the research.

\section{Data collection}

Data were collected using a combination of surveys, interviews and focus groups. At one of the case study projects (project 4) additional data were collected using a daily diary, completed by project participants over the course of a working week. Surveys utilised previously validated psychometric measures of perceived managerial support for work life balance (example item 'In the event of conflict, managers are understanding when non-work responsibilities are put first'); work-to-home conflict (example item 'The amount of time my job takes up makes it difficult to fulfil non-work responsibilities'); home-to-work conflict (example item 'I have to put off work because of demands on my time at home'); and organizational time demands (example item 'To get ahead, employees are expected to work more than 50 hours each week'). Items were rated on a seven point Likert scale ranging from 1 (strongly disagree) to 7 (strongly agree). A principal components analysis revealed that a four factor solution, explaining $65.2 \%$ of total variance, best fit the survey data. ${ }^{1}$ The mean score for items loading on each principal component was calculated and this mean was used in the subsequent data analysis.

In addition, data collected at project three included single-item measures of satisfaction with work time and satisfaction with work-life balance. Participants were asked to indicate their

\footnotetext{
${ }^{1}$ The principal components analysis is available upon request from the first-named author
} 
level of satisfaction with their working time arrangements and work-life balance at the projects by rating them on a seven point scale ranging from 1 (very dissatisfied) to 7 (very satisfied). More information on the source of survey questions is available in Lingard, Brown, Bradley, Bailey \& Townsend (2007).

Demographic details were also sought from participants, including sex, age, family structure and occupation, in particular whether participants were waged or salaried staff. Post intervention surveys requested respondents to indicate the impact of the intervention on their work-life balance. The pre-intervention semi-structured interviews and focus groups explored participants' experiences in balancing work and personal lives, work hours and workload, preferences for different types of work-life support and perceptions about their ability to negotiate work-life support if necessary. The post-intervention interviews also explored participants' work-life experiences following the introduction of the intervention, in particular whether they felt better able to balance their work and personal lives. The diary data collection required participants to orally record their thoughts on a personal digital assistant (PDA) three times each day; 8am; 1pm and 8pm. Participants were asked at 8am to explain their work hours and work-life balance expectations for the day. At 1pm, participants were asked to report on how their day had 'evolved' and whether the expectations they expressed at $8 \mathrm{am}$ were likely to be met. At 8pm were asked to reflect on the day focusing on whether (and how) work had impacted on their work-life balance.

\section{Research design}

Differences in the timing and level of access provided to researchers to each of the case study projects prohibited the use of a consistent experimental design, which impacted upon the internal validity of the research and ability to make causal inferences about the effect of the interventions. In two cases (projects 2 and 4), the work-life interventions had already been implemented prior to researchers gaining access to project personnel, allowing only a post hoc analysis of the impact of the interventions. In one project (project 3) baseline (i.e. preintervention) conditions were investigated using surveys but post-intervention data collection was limited due to the very small numbers of site personnel that utilised the intervention. In only one case (project 1) was data collected before and after the implementation of the worklife intervention.

\section{Case study projects}

All of the case study projects involved civil engineering construction, including two road construction projects. The remaining projects involved the construction of water infrastructure, a dam and a water treatment facility. All of the four projects were procured as project alliances. One defining feature of project alliancing is that participants are selected on the basis of their capability, approaches and systems as well as their commitment, chemistry and the likelihood of them delivering outstanding results (Hutchinson and Gallagher 2003).Unlike traditional selection processes, in project alliancing, participants are selected before a price is considered. Typically, project alliance objectives extend beyond the traditional emphasis on price, to include the ability to innovate and manage relationships within and between alliance participants. In total 447 construction industry workers were involved in the data collection, with a relatively even split between waged and salaried workers.

Table 1 presents a summary of the case study construction projects as well as the interventions and data collection methods implemented at each of these projects. 
Table 1: Project descriptions and summary of interventions and data collection

\begin{tabular}{|c|c|c|c|c|}
\hline Case & Description & Procurement & Intervention & Data collection \\
\hline Project 1 & $\begin{array}{l}\text { Road } \\
\text { construction }\end{array}$ & $\begin{array}{l}\text { Project } \\
\text { alliance }\end{array}$ & $\begin{array}{l}\text { (1) Compression of } \\
\text { the work week } \\
\text { (2) Alternative } \\
\text { rostering to reduce } \\
\text { Saturday work }\end{array}$ & $\begin{array}{l}\text { (1) Baseline survey } \\
\text { (2) Pre-intervention focus } \\
\text { groups } \\
\text { (3) Post-intervention survey } \\
\text { (4) Post-intervention } \\
\text { interviews } \\
\text { (5) Monthly episodic } \\
\text { interviews pre- and post } \\
\text { intervention. }\end{array}$ \\
\hline Project 2 & $\begin{array}{l}\text { Dam } \\
\text { construction }\end{array}$ & $\begin{array}{l}\text { Project } \\
\text { alliance }\end{array}$ & $\begin{array}{l}\text { (1) Compression of } \\
\text { the work week }\end{array}$ & $\begin{array}{l}\text { (1) Post intervention survey } \\
\text { (2) Post intervention } \\
\text { interviews } \\
\text { (3) Six month 'lag' post- } \\
\text { intervention interviews }\end{array}$ \\
\hline Project 3 & $\begin{array}{l}\text { Road } \\
\text { construction }\end{array}$ & $\begin{array}{l}\text { Project } \\
\text { alliance }\end{array}$ & $\begin{array}{l}\text { (1) Optional change } \\
\text { to a five day week }\end{array}$ & $\begin{array}{l}\text { (1) Baseline survey } \\
\text { (2) Post-intervention } \\
\text { interviews }\end{array}$ \\
\hline Project 4 & $\begin{array}{l}\text { Water } \\
\text { treatment } \\
\text { facility } \\
\text { construction }\end{array}$ & $\begin{array}{l}\text { Project } \\
\text { alliance }\end{array}$ & $\begin{array}{l}\text { (1) Compulsory } \\
\text { change to a five day } \\
\text { week (which was } \\
\text { reversed); } \\
\text { (2) Alternative } \\
\text { rostering to reduce } \\
\text { Saturday work for } \\
\text { salaried employees. }\end{array}$ & $\begin{array}{l}\text { (1) Post-intervention } \\
\text { interviews } \\
\text { (2) Daily diary data collection }\end{array}$ \\
\hline
\end{tabular}

\section{Results}

The size and characteristics of the participants (i.e. whether they are waged or salaried) is briefly described. Following this, the results of an analysis of data collected at each of the participating construction projects will be presented.

Table 2 shows the number of participants for each data collection method at each of the case study projects. The numbers of waged workers who participated in the questionnaire survey was slightly higher than the number of salaried workers. However, more salaried than waged workers participated in long interviews and no waged workers completed the diary component of data collection. The numbers of waged and salaried workers participating in focus groups and short episodic interviews was approximately equal. 
Table 2: Sample size and breakdown of waged and salaried participants at each case study project

\begin{tabular}{|c|c|c|c|c|}
\hline Data collection method & Project 1 & Project 2 & Project 3 & Project 4 \\
\hline \multirow[b]{2}{*}{ Questionnaire } & Yes & Yes & Yes & \multirow[b]{2}{*}{ N/A } \\
\hline & $\begin{array}{l}\text { Time } 1 \\
\mathrm{w}=52 \\
\mathrm{~s}=41 \\
\text { ( } 2 \text { unsure) } \\
\text { Time } 2 \\
\mathrm{w}=68 \\
\mathrm{~s}=42 \\
(2 \text { unsure) }\end{array}$ & $\begin{array}{l}\mathrm{w}=28 \\
\mathrm{~s}=14\end{array}$ & $\begin{array}{l}\mathrm{w}=22 \\
\mathrm{~s}=57\end{array}$ & \\
\hline \multirow{2}{*}{$\begin{array}{l}\text { Long interviews } \\
\text { (approximately } 1 \text { hour) }\end{array}$} & \multirow[b]{2}{*}{ N/A } & Yes & Yes & Yes \\
\hline & & $\begin{array}{l}\mathrm{w}=7 \\
\mathrm{~s}=12\end{array}$ & $\begin{array}{l}\mathrm{w}=6 \\
\mathrm{~s}=14\end{array}$ & $\begin{array}{l}\mathrm{w}=5 \\
\mathrm{~s}=11\end{array}$ \\
\hline \multirow[b]{2}{*}{$\begin{array}{l}\text { Short episodic interviews } \\
\text { (15 minutes) }\end{array}$} & Yes & \multirow{2}{*}{ N/A } & \multirow{4}{*}{ N/A } & \multirow{4}{*}{ N/A } \\
\hline & $\begin{array}{l}w=5 \\
s=6\end{array}$ & & & \\
\hline \multirow[b]{2}{*}{ Focus groups } & Yes & \multirow[b]{2}{*}{ N/A } & & \\
\hline & $\begin{array}{l}\text { Groups } \\
\mathrm{w}=8 \\
\mathrm{~s}=8\end{array}$ & & & \\
\hline Diary study & N/A & N/A & N/A & $\begin{array}{l}\text { Yes } \\
s=16\end{array}$ \\
\hline
\end{tabular}

Note: $w$ denotes the number of waged participants, $s$ denotes the number of salaried participants.

\section{Project 1 (road construction)}

Survey data were collected from workers at project 1 both before and after the implementation of a compressed work week. In December 2006, a pre-intervention survey was completed by 95 workers at project 1 . Shortly afterwards, the site changed from a six day working week to a five day working week. The revised roster followed a four week cycle, such that workers enjoyed 2 'two day' weekends, 1 'one-day' weekend, and one 'three day' weekend every four weeks. Site hours were extended from $7 \mathrm{am}$ to $5 \mathrm{pm}$ on weekdays to $6.30 \mathrm{am}$ to $5 \mathrm{pm}$, and from $6.30 \mathrm{am}$ to $3 \mathrm{pm}$ on the one Saturday worked each month. In December 2007, follow-up surveys were conducted to determine whether work-life experiences were different under the new roster. Table 3 shows the results of these surveys. Comparisons of the mean scores indicate that workers' perceptions managerial support for work-life balance were not significantly different between the pre-and post intervention surveys. In addition, there was no significant change in the perception of home-to-work conflict. There was a greater reduction in workers' perception of the organizational work hours expectations between the pre-and post-intervention surveys, although this was not statistically significant. A t-test revealed that the reduction in perceived work-to-home 
conflict between the pre-and post-intervention surveys was statistically significant $(\mathrm{t}=2.1$, $\mathrm{p}=.04)$.

In January 2007 (before the intervention was introduced), four focus groups were conducted with workers at project 1 . Two focus groups involved salaried workers and two involved waged workers. These two groups reported different work-life balance difficulties, but some themes were consistent. Overwhelmingly, the salaried staff felt a sense of low levels of worklife balance stemming from their long working hours. Employees continually state they have little time or energy to enjoy their non-work activities. Many of the employees state that they simply opt out of social activities because of work stresses that continue after leaving their workplace. The question of manageable workloads was cited as the major impediment to reducing hours, along with a 'culture' of long hours in the industry. Salaried workers also indicated that they received conflicting messages about the work hours expectations from their supervisors/managers. For example, one participant commented:

'When I am there after five (pm) my bosses come around and tell me to go home ... at the same time there is that high amount of workload, so that if you don't get something done, it might be tomorrow or the next day that somebody says "why haven't you done this?",

Waged workers frequently highlighted inadequate resources leading to unnecessary delays and increased time pressure. Issues associated with the scheduling and planning of some tasks giving rise to delays, frustrations and confrontation were also frequently cited as impediments to work-life balance. Post-intervention interviews were conducted with workers at project 1 between August and December 2007. The responses were generally positive, with participants commenting on the benefits associated with increased control over their time. For example, one commented:

'Generally overall I feel like I have got more control over my time to do the things I want to do, so um, even though the days are longer, I am actually doing more in a normal day, which is a bit bizarre, so I am getting up earlier and going and doing some exercise, and doing things, because I know I have got my weekends.'

Although waged workers expressed some concern about the impact of the revised schedule on their pay. For example, one commented:

'I appreciate the extra time for sure, it is great to spend it with my family on Saturdays...[but] I've only got one income coming in so the extra Saturday really did come in handy. Other than that, it is good... I like the time with the kids. I'm able to go and watch my son play soccer, or take him fishing instead of having just one day to do it.' 


\begin{tabular}{lcccc} 
& Date & N & Mean & $\begin{array}{c}\text { Standard } \\
\text { Deviation }\end{array}$ \\
$\begin{array}{l}\text { Managerial support for work-life } \\
\text { balance }\end{array}$ & December 2006 & 92 & 4.82 & 1.18 \\
& December 2007 & 111 & 4.86 & 1.17 \\
$\begin{array}{l}\text { Organizational work hours } \\
\text { expectations }\end{array}$ & December 2006 & 94 & 4.51 & 1.37 \\
$\begin{array}{l}\text { Home-to-work conflict } \\
\text { December 2007 }\end{array}$ & December 2006 & 111 & 4.10 & 1.49 \\
Docember 2007 & 94 & 2.43 & 1.18 \\
\hline
\end{tabular}

\footnotetext{
${ }^{\mathrm{a}}$ The mean score is the mean of survey items loading on this principal component

*denotes a statistically significant difference between Time 1 and Time 2 scores.
}

\section{Project 2 (dam construction)}

The research project commenced after the compressed work week had already been implemented at project 2 , meaning that data could only be collected after the intervention. The compressed work week, which involved reducing the length of the working week, but increasing the length of the working day, was introduced part-way through the construction phase of project 2. At the commencement of the construction project, the site was operating on (approximately) a 58 hour week, spread over six days. This comprised five ten hour days (Monday to Friday) plus an eight hour day on Saturday. Shortly before data collection commenced in March 2005, the site moved to a five day week, with working hours extended to 11.5 hour per day on week days. Weekend work was no longer required. By May 2005, the site was operating on winter hours, reducing work hours further to 10.5 hours per day. Questionnaires were administered to workers at the project 2 site in June 2005. The questionnaires were designed with the objective of evaluating employees' reactions to the move from a six to five day week. Semi-structured interviews were also conducted with workers at project 2 .

The survey respondents rated their preferences for the compressed work week on a seven point scale, where ' 1 ' = 'very strongly prefer five day week' and ' 7 ' = 'very strongly prefer six day week.' The mean score was $1.79(\mathrm{sd}=1.55)$, indicating a strong collective preference for the five day week. The numbers of workers for each response option are indicated in Table 4. Table 4 shows that the majority of both wages and salaried employees expressed a preference for the five day week. However, a small number of wages staff indicated that they either had no preference or preferred to work a six day week. 


\begin{tabular}{lccc}
\hline & Combined & $\begin{array}{c}\text { Numbers of Staff } \\
\text { Wages Only }\end{array}$ & Salary Only \\
Very strongly prefer 5 day & 30 & 14 & 16 \\
Prefer 5 day & 4 & 3 & 1 \\
Slightly prefer 5 day & 2 & 1 & 1 \\
No preference & 3 & 2 & 1 \\
Slightly prefer 6 day & 0 & 0 & 0 \\
Prefer 6 day & 2 & 2 & 0 \\
Very strongly prefer 6 day & 1 & 1 & 0 \\
\hline
\end{tabular}

Many salaried respondents also identified 'knock-on' effects for work (e.g. productivity and loyalty to the organisation) and non-work activities (e.g. family activities and domestic duties). For example, one commented:

'In the last $(x)$ years I've always worked a six day week and was often stressed and tired by Saturday. On this job I've felt very relaxed on the weekend ....... I've also been able to complete all my jobs around the house. Our crew is happier because their money hasn't changed much and they have a life. I personally think that productivity has been excellent because everybody is fresh and happy.'

Several salaried respondents directly linked the five day week to employee retention. For example, one commented:

'A commitment to pursue a five day week across the business would help people make loyal decisions at project completion ...' and another said

'A five day week is what I and my family now demand. I will not work six days again, even if it means changing to another industry.'

In contrast, only two waged workers provided further comments at the end of their questionnaires and both of these comments related to the concerns of waged workers that revised work scheduled should not impact upon their weekly 'take-home' pay.

\section{Project 3 (road construction)}

At the commencement of the research involvement with project 3 , the site was working a standard six day week. As was the case with project 1, workers at the project 3 site were surveyed before the introduction of an intervention to identify their baseline perceptions of work-life balance. The mean scores for work-life variables measured in this survey are provided in Table 5, which shows that workers at project 3 perceived that their home life did not interfere with work to a great extent (Mean home-to-work conflict score $=2.58$ ) but that their work life was perceived to interfere with home life to a far greater extent (Mean workto-home conflict score $=4.88$ ) 


\begin{tabular}{|c|c|c|}
\hline & $\mathrm{N}$ & Mean $^{a}$ \\
\hline $\begin{array}{l}\text { Managerial support for work-life } \\
\text { balance }\end{array}$ & 79 & 4.33 \\
\hline Work-to-home conflict & 79 & 4.88 \\
\hline Home-to-work conflict & 79 & 2.58 \\
\hline Organizational time demands & 79 & 4.65 \\
\hline $\begin{array}{l}\text { Satisfaction with working time } \\
\text { arrangements }\end{array}$ & 79 & 4.20 \\
\hline $\begin{array}{l}\text { Overall satisfaction with work life } \\
\text { balance }\end{array}$ & 79 & 4.00 \\
\hline
\end{tabular}

Following the baseline survey, the management team at project 3 decided to introduce an optional five day week. The reason that this was an optional five day working week was because the project manager recognised that there was a work-life balance problem in the workplace, however, external pressures to complete the job were high. Indeed the project manager told the research team that:

'We're six months ahead of schedule and we got that way with no work-life balance so we're going to keep going'.

Consequently, the five-day working week was only available to workers who could demonstrate a 'personal need' for the change. To utilise the option, workers also had to demonstrate that their work would not be adversely affected by the changed work schedule. Unlike the compressed work week implemented at projects 1 and 2, at project 3, work hours between Monday and Friday were not extended. This meant that waged workers who decided to work five days would sacrifice a portion of their take home pay as a result. Fewer than 20 out of greater than 300 workers opted to change their schedules. All workers who changed their schedule were salaried workers. Eight of those who made the change were interviewed after they had done so. Comments made by interviewees suggest that work-life balance was not significantly improved and that the culture of long hours was maintained at project 3 . For example, one commented:

'Everyone is always here at 7am, and everyone is always here at 5 o'clock. Most people grab a sandwich for ten minutes to have their lunch, and stuff like that. Even without working on Saturdays, there are some people who are still here at 7 or 8 o'clock at night.'

Another commented:

'I still don't believe I've got a work/life balance... My wife would severely criticise my attendance to the family, because work does have a reasonably substantial demand on my week.'

The component of individual choice requiring potential users of the intervention to consider the trade-off between wages and time was noted by participants. One commented:

'It is up to the individual to decide what they prefer, the money or the time. I mean it is a fairly simply transaction.'

\section{Project 4 (water treatment facility construction)}

The management team at project 4 decided, prior to the commencement of the construction phase of the project, work, that the site would only work a five-day week. The motivation for this was to reduce working hours and provide workers with a greater opportunity for 
involvement in non-work activities. Under this arrangement, the site would work a standard ten hour day from Monday to Friday. Weekday hours were not extended as in the compressed work weeks at projects implemented at projects 1 and 2. Thus, waged workers at project 4 stood to lose 'premium' Saturday penalty rates - often 1.5 times their standard hourly rate for the first four hours and then double time for the remaining hours. Hence, a shorter Saturday could be financially worth almost two standard days of work. The decision to work a five day week was made during winter months, with the result that daylight constraints limited workers' ability to work extended overtime between Monday and Friday. When another large construction project commenced nearby the site of project 4 , a large number of waged workers left project 4 to work on the nearby project. The project manager indicated that he believed this was because the waged workers were able to earn more money each week working a six day week at the competitor's project, including higher rates of pay for work undertaken outside the standard work week. This evidence is purely anecdotal and does not necessarily reflect the fact that other causes for this departure may also have existed. In the opinion of managers at Project 4, the turnover in workforce was made worse because the waged workers who did not move to the newly commenced construction site nearby (as well as those recruited to compensate for loss of workforce at project 4) were less experienced, skilled and productive. Indeed, the management team expressed the belief that the loss of skilled workers that occurred at project 4 was, to a large extent, the cause of a slip in project performance against schedule that occurred around this time. As a result of these occurrences, the management group at project 4 made the decision to revert back to the industry standard six-day working week. This allowed (but did not require) waged workers to work Monday to Saturday. Salaried employees were placed on a roster system, according to which they were required to work between one-in -two to one-in-four Saturdays each month. It was following this reversal of the five day week schedule that the research team were invited to collect data on project 4. Thus, no data were collected during the period of the intervention. In September 2005 interviews were conducted with 16 site workers from project 4 . In November 2005, another 16 salaried employees at project 4 participated in a daily diary data collection exercise.

Waged workers at project 4 appreciated having a two day weekend. For example, comments made by waged workers include:

'All of us would probably prefer a five day week to be home with the kids, and taking them to sport and all that sort of stuff. I mean I would be quite happy to do a full day Monday to Friday...' and

'... I think they all agree that the long hours, if they can get the two days off, you get much more rest out of two days then out of just one day."

However, the reduced weekly pay resulting from the five day week was a source of dissatisfaction to a large number of waged workers at project 4 . For example, one commented:

'But the money is what you need to cover the mortgage and everything like that. I love the short hours...but again the money side of things.'

In contrast, salaried workers at project 4 were much more positive about the five day week. The following comment illustrates the positive benefits perceived by salaried workers. '(the five-day week)...gave my three kids a chance to do sport. My wife could only take two of them to sport, (so one child) always missed out... This job here is a lot better (than previous six-day jobs).' 
Even when the site reverted to the six day schedule, salaried employees at project 4 were very satisfied with the roster system for weekend work. For example, one salaried employee who works every second Saturday, commented:

'[the five-day week]...it makes you feel better inside, because you are thinking "I've got the Saturday off" and you think "oh Great" and it makes you do your job better, you feel more comfortable, and you're happier doing what you're doing.'

The diary recordings at project 4 revealed that unexpected events and interruptions were a significant source of disruption to salaried employees' work days and a source of pressure to work extended hours to make up lost time. For example, diary study participants commented: 'A couple of unexpected things have cropped up...the rest of the day I will have to spend trying to catch up, but will I (catch up)?'

'Today is not going as planned. We have to change our priorities...it's like a dog chasing its tail.'

'(rain is) going to set us back a bit, not much we can do about it. Just means more work to get done tomorrow.' and

'We have got to move some things that were in the wrong position yesterday, as a result of reading the wrong drawing. We never get everything done that we need to during the day...'

\section{Discussion}

\section{Structural properties of the Australian construction labour market}

The results of the research highlight structural challenges to the reduction of work hours and the adoption of alternative work schedules in the Australian construction industry. The research data indicate that the elimination of work on Saturday was favourably perceived by workers (irrespective of whether they were waged or salaried) at participating construction projects. Frequently cited benefits of having a two-day break included the increased opportunity for rest and recuperation and participation in family activities, which workers indicated they did not enjoy when working a six day week.

However, our results also confirm the existence of two distinct groups of worker within the Australian construction industry, operating in distinct labour markets. In this context, managerial, professional, administrative and supervisory workers (e.g. foremen) are salaried, meaning that they are paid a fixed annual salary irrespective of the hours they work each week. In contrast, skilled and unskilled tradesmen and labourers (site-based, blue collar workers) are paid an hourly wage. This is based upon an hourly rate up to a standard work week, above which penalty rates (usually one and a half times the standard hourly rate) are paid for overtime. This penalty rate also applies to weekend work.

This means that capping the hours of work undertaken between Monday and Friday and/or eliminating Saturday work impacts quite differently upon these two groups. All other things being equal, reducing work hours (especially those performed outside the standard work week, and hence which earn penalty rate payments), will significantly reduce the weekly 'take home' pay of waged workers, but will have no impact upon the payment of salaried workers. 
Our results suggest that this difference strongly influences workers' responses to alternative work schedules.

It is noteworthy that the projects at which the alternative work schedule interventions were most successful (projects $1 \& 2$ ) opted to implement a compressed work week (i.e.

lengthening the work day between Monday and Friday and eliminating Saturday work). This enabled the alternative work schedule to be implemented, while maintaining the same level of pay for waged workers. Our results show this to be much more effective than when a standard 10 hour days was maintained and Saturday work was eliminated. In project 3, this was offered as an option to workers (as long as they satisfied certain criteria). However, the uptake of this arrangement was extremely low and no waged workers opted to make the change, with the result that this alternative work schedule intervention had minimal beneficial impact upon workers' work-life balance at project 3 . The experience of project 4 was more dramatic. The change from a six day week to a standard 10 hours x 5 days schedule brought the unintended consequence that many waged workers left the project to work at another construction project that provided the opportunity to work Saturdays, and hence earn more hours paid at the overtime penalty rate.

Economists try to explain labour supply preferences based upon a trade-off between hours and wages. Thus, individuals are believed to consider whether the net gain (income minus tax) from working an additional hour is worth foregoing that hour of leisure/family time (Altjoni $\&$ Paxson, 1988). The difficulty of this model is it assumes that workers have the freedom to move between employment options and are free to choose their hours of work, thereby achieving their optimal combination of hours and leisure time. However, this is not likely to be the case as employers seek to reduce costs associated with inducting new workers and maximise return on investments in training and development by hiring workers for a minimum required number of hours - a phenomenon known as 'lumpiness' in labour demand (Van Echtelt, Glebbeek \& Lindenberg, 2006). Similarly, Bryan (2007) questions the extent that workers are actually free to choose their work hours, suggesting that the influence of employer demands (for example, for long and rigid work schedules) significantly shape work hours 'choices.'

Our results suggest that work hours are partially driven by employer demand in the construction context. The required long and unsocial hours are not favoured by workers, who report negative impacts on wellbeing and family life. A reduction in hours via the elimination of Saturday work was very strongly favoured by salaried workers at all of the case study projects. This is perhaps unsurprising as it would constitute an increase in leisure time at no financial cost to salaried workers. In contrast, waged workers at all sites expressed concerns about the impact of alternative work schedules on their take-home pay, even when this was maintained by the compression of the work week (projects 1 and 2). The payment of overtime at penalty rates likely changes the nature of the wage-leisure trade off at the margin and creates an incentive to work longer hours and weekends. Reynolds (2005) also reports that US-based workers who are paid an hourly rate with loading for overtime are less likely to want to reduce their work hours than salaried workers.

The exercise of individual choice concerning work hours was dramatically evidenced by the experience of project 4, in which Saturday work was eliminated and a significant number of waged workers left to project to work at another project in the area, which was still working a six day week. 


\section{Implications for the management of construction projects}

Our results indicate that there are no easy solutions to the problems of working time and the resolution of work-life conflict in the Australian construction context. Labour market characteristics create two distinct groups of worker with different (opposing) interests in relation to work schedules. With the exception of Drago, Costanza, Caplan, Brubaker, Cloud, Harris, Kashian. \& Riggs (2001), who explored the extent to which US school teachers would be willing to accept a reduction in pay in return for various work-family benefits, few empirical studies have considered the implications of the wages-leisure time trade off for workers' preferences for work-life policies. Our results suggest that the wage implications of work-life strategies form a critical determinant of their viability and ultimate effectiveness. The practical implication for the management of construction projects is that (under current labour market conditions), alternative work schedules are only likely to succeed when they are implemented in such a way as to maintain waged workers take home pay. In two of the case study projects (projects $1 \& 2$ ) this was achieved by lengthening the working day between Monday and Friday. However, our interview data indicated that this resulted in problems with worker fatigue, which could potentially have serious consequences for project performance in critical areas, such as safety (Smith, Folkard, Tucker \& MacDonald 1998).

Ultimately the provision for work-life balance needs to be considered in construction project planning and innovative ways of resourcing projects and remunerating workers built into terms and conditions via the enterprise bargaining process. One problem is the continuing practice of equating hours spent at work with productive time. There is considerable anecdotal evidence $^{2}$ to support the argument that productivity is lower on Saturdays than other days of the week, suggesting that time spent at work may not be the best basis for determining the 'value' of work.

One model implemented by the Acton Peninsula Alliance Management Team during the construction of the National Museum of Australia involved the use of performance-based bonus payments. Under this model, benchmarks were established for project performance components. Performance was measured against these benchmarks by an independent panel before bonus payments were made. The traditional site allowance payment ${ }^{3}$ was replaced with a sliding scale payment based upon productivity and proven performance. The project experienced few industrial relations problems and no days were lost due to industrial action (Walker et al. 2001). This was unusual for high profile construction projects sponsored by the Australian Federal Government. The scope for replacing time-based remuneration with performance-based remuneration to overcome concerns about alternative work schedules should be explored in future work-life balance case studies in the construction industry.

\section{Alliancing}

It is noteworthy that all four case study projects were alliances. Alliancing has become a popular delivery strategy in the Australian construction industry, particularly in the case of major public sector infrastructure projects. In an alliance project, alliance participants (client,

\footnotetext{
${ }^{2}$ This anecdotal evidence is based upon the fact that there are considerable constraints placed, by local by-laws, upon construction work that can be undertaken on a Saturday. For example, noisy activities are prohibited before a specified time.

${ }^{3}$ On many Australian construction sites the trade union has negotiated comprehensive project agreements that provide for the payment of an allowance over and above the normal hourly rate. This allowance increases as the project value increases.
} 
designers and constructors) form a cohesive entity which jointly shares the risks and rewards arising during and as a result of the project. As such, poor performance results in penalty to all alliance participants and, conversely, rewards for excellent performance are shared between the participants. Put simply, "a fundamental design principle of a project alliance commercial framework is that if one participant wins, all win; or if one loses, all lose." (Hutchinson and Gallagher, 2003, p.18). In the context of shared risk, the likelihood that innovative solutions to problems will be identified and implemented is greatly increased (Walker et al 2002; Hutchinson and Gallagher 2003). Thus, at the case study projects, the risk associated with implementing alternative work schedules was shared between participants, who also all stood to gain if the measures improved productivity and performance.

\section{Conclusions}

Our results were limited in two important respects. First, practical experimental design constraints prevent us from conclusively claiming causality between the alternative work schedules and work-life outcomes. However we suggest we are providing enough evidence to support a link between these work-life interventions and improved work-life balance for employees. Second, our results are based upon data collected at a small number of case study projects, all of which used an alliance delivery mechanism, the findings are unlikely to be externally generalizable. Notwithstanding this, our results confirm that policy concerns about work hours and work-life balance in the construction industry are well justified. The perception of many Australian workers (including those in construction) is that they are working more hours than they would like, (a state known as 'over-employment') which impacts upon perceptions of work-life balance. The need for family friendly work arrangements has become an important feature of government campaigns and community demands, yet these appear to be at odds with persistent patterns of work in the construction industry. Neither do we know to what extent the long work hours 'culture' of the construction industry is an artefact of Australia's work hours regime, in which hours are established for different groups of workers by a mixture of industry collective agreement, enterprise bargaining and individual contract. Unlike Europe, Australia's working time regime places no statutory limits on the number of hours worked and is based upon a de-regulated marketdriven model of economic growth. Future international comparative research should explore institutional and structural issues relevant to the implementation and effectiveness of alternative work schedules to improve the work-life balance of project-based construction workers.

\section{Acknowledgement}

The research was funded by an Australian Research Council Linkage Project Grant. The authors gratefully acknowledge the funding support of the Construction Industry Institute of Australia.

\section{References}

Altonji, J. G. \& Paxson, C. H., (1988), Labor supply preferences, hours constraints and hours-wage trade-offs, Journal of Labor Economics, 6, 254-276.

Baltes, B. B., Briggs, T. F., Huff, J. W., Wright, J. A. \& Neuman, G. A., (1999), Flexible and compressed workweek schedules: a meta analysis of their effects on work-related criteria, Journal of Applied Psychology, 84, 496-513.

Batt, R. \& Valcour, P.M. (2003). Human resources practices and predictors of work-family outcomes and employee turnover. Industrial Relations, 42, 189 - 220.

Broschak, J. P., Davis-Blake, A. \& Block, E. S. (2008), Nonstandard, Not Substandard: The relationship among work arrangements, work attitudes and job performance, Work and Occupations, 35, 3-43.

Bryan, M. L., (2007), Free to choose? Differences in the hours determination of constrained and unconstrained workers, Oxford Economic Papers, 59, 226-252.

Campbell, I (2002) 'Extended Working Hours in Australia' Labour and Industry, 13 (1) pp. 91-110. 
Campbell, I (2005) 'Long Working Hours in Australia: Working Time Regulations and Employer Pressures' Centre for Applied Social Research Working Paper Series, Number 2005-2, Royal Melbourne Institute of Technology, Melbourne.

Casper, W. J. \& Buffardi, L. C., (2004), Work-life benefits and job pursuit intentions: the role of anticipated organizational support, Journal of Vocational Behavior,.65, 391-410.

Clarkberg, M. and P. Moen (2001) 'Understanding the time squeeze: Married couples' preferred and actual workhour strategies', American Behavioural Scientist 44: 1115-36.

Crouter, A. C., Bumpus, M. F., Head, M. R. \& McHale, S. M., (2001), Implications of overwork and overload for the quality of men's family relationships, Journal of Marriage and the Family, 63, 404-416.

Drago, R., Costanza, D., Caplan, R., Brubaker, T., Cloud, D., Harris, N., Kashian, R. \& Riggs, T. L., (2001), The willingness to pay for work/family policies: a study of teachers, Industrial and Labor Relations Review, 55, $22-41$

Gershuny, J., Bittman, M. \& Brice, J. (2005). Exit, voice and suffering: Do couples adapt to changing employment patterns? Journal of Marriage and the Family, 67, 656-665.

Hosking, A. \& Western, M., (2008), The effects of non-standard employment on work-family conflict, Journal of Sociology, 44, 5-27.

Human Rights and Equal Opportunity Commission (2007) 'It's about time: women, men, work and family'. Canberra: HREOC.

Hutchinson, A., \& Gallagher, J. (2003). Project alliances: an overview, Alchimie Pty Ltd and Phillips Fox Lawyers. First issued as the Centre of Advanced Engineering Seminars, Auckland and Christchurch, New Zealand, March 2003.

Jamal, M., (2004), Burnout, stress and health of employees on non-standard work schedules: a study of Canadian workers, Stress and Health, 20, 113-119.

Kelly, E. L. \& Kalev, A., (2006), Managing flexible work arrangements in US organizations: formalized discretion or 'a right to ask', Socio-Economic Review, 4, 379-416

Kodz, J., S. Davis, D. Lain, E. Sheppard, J. Rick, M. Strebler, P. Bates, J. Cummings, N. Meager, D. Anxo, S. Gineste and R. Trinczek (2003) 'Working long hours in the UK: A review of the research literature, analysis of survey data and cross-national organizational case studies'. London: Department of Trade \& Industry.

Latack, J. C. \& Foster, L. W., (1985), Implementation of compressed work schedules: participation and job redesign as critical factors for employee acceptance, Personnel Psychology, 38, 75-92

Lingard, H. \& Francis, V., (2002), Work-life issues in the Australian construction industry: the results of a pilot study, (Report prepared for and submitted to the Construction Industry Institute of Australia).

Lingard, H. and Francis, V., (2004) - The work-life experiences of office and site-based employees in the Australian construction industry, Construction Management and Economics, 22, 991-1002.

Lingard, H., Brown, K., Bradley, L., Bailey, C. \& Townsend, K., (2007), Improving employees' work-life balance in the construction industry: A project alliance case study, ASCE Journal of Construction Engineering and Management, 133: pp. 807-815.

Moen, P. \& Yu, Y., (2000), Effective work/life strategies: working couples, work conditions, gender and life quality, Social Problems, 47, 291-326.

Peetz, D, Townsend, K, Russell, B, Houghton, C, Fox, A \& Allan, C (2003) 'Race Against Time: Extended Hours in Australia' Australian Bulletin of Labour, 29 (2), 126-142.

Presser, H. B. (2000) Nonstandard work schedules and marital instability. Journal of Marriage and the Family, 62, 93-110.

Reynolds, J., (2005), In the face of conflict: work-life conflict and desired work hour adjustments, Journal of Marriage and Family, 67, 1313-1331.

Reynolds, J. \& Aletraris, L., (2007), Work-family conflict, children, and hour mismatches in Australia, Journal of Family Issues, 28, 749-772.

Shepanski, P. \& M. Diamond (2007) 'An Unexpected Tragedy: Evidence for the connection between working patterns and family breakdown in Australia'. Sydney: Relationships Forum Australia.

Shockley, K. M. \& Allen, T. D., (2007), When flexibility helps: Another look at the availability of flexible work arrangements and work-family conflict, Journal of Vocational Behavior, 71, 479-493.

Smith, S., Folkard, S., Tucker; P. \& Macdonald, I., (1998), Work shift duration: a review comparing eight hour and 12 hours shift systems, Occupational and Environmental Medicine; 55, 217-229.

Stavrou, E. T., (2005), Flexible work bundles and organizational competitiveness: a cross-national study of the European work context, Journal of Organizational Behavior, 26, 923-947.

Strazdins, L., Clements, M. S., Korda, R. J., Broom, D. H. \& D’Souza, R. M., (2006), Unsociable work? Nonstandard work schedules, family relationships and children's wellbeing, Journal of Marriage and the Family, 68, 394-410. 
Tausig, M. and Fenwick, R., (2001), Unbinding time: alternative work schedules and work-life balance, Journal of Family and Economic Issues, 22, 101-119.

Thornwaite, L. \& Sheldon, P., (2004), Employee self-rostering for work-family balance, Employee Relations, 26, 238-254.

Ulker, A. (2006) Do non-standard working hours cause negative health effects? Some evidence from panel data, Canberra: Centre for Economic Policy Research Discussion Paper, Australian National University.

Van Echtelt, P. E., Glebbeek, A. C. \& Lindenberg, S. M., (2006), The new lumpiness of work: explaining the mismatch between actual and preferred working hours, Work, Employment and Society, 20, 493-512.

Van Wanrooy, B. \& Wilson, S., (2006), Convincing the toilers? Dilemmas of long working hours in Australia, Work, Employment and Society, 20, 349-368.

Veiga, J. F., Baldridge, D. C. and Eddleston, K. A., (2004), Towards understanding employee reluctance to participate in family-friendly programs, Human Resource Management Review, 14, 337-351.

Walker, D. H. T., Hampson, K., and Peters, R. (2002). "Project alliancing vs project partnering: a case study of the Australian National Museum Project.” Supply Chain Management, 7, 83-91.

Wharton, A. S. \& Blair-Loy, M., (2006), Long work hours and family life: A cross-national study of employees' concerns, Journal of Family Issues, 27, 415-436.

White, L. \& Keith, B. (1990). The effect of shift work on the quality and stability of marital relations. Journal of Marriage and the Family, 52, 453 - 462. 